\title{
Chromogenic Limulus Amoebocyte Lysate Assay for Rapid Detection of Gram-Negative Bacteriuria
}

\author{
RONALD NACHUM ${ }^{1 *}$ AND RONALD N. BERZOFSKY \\ Department of Pathology, King-Drew Medical Center, Los Angeles, California 90059, ${ }^{1}$ and Whittaker M. A. Bioproducts, \\ Walkersville, Maryland $21793^{2}$
}

Received 6 December 1984/Accepted 6 February 1985

\begin{abstract}
A chromogenic Limulus amoebocyte lysate assay was evaluated as a rapid screening test for the detection of clinically significant gram-negative bacteriuria. The development of a distinctive yellow color after the addition of chromogenic substrate to the Limulus amoebocyte lysate-urine reaction mixture was used to measure $\geq 10^{5}$ gram-negative bacteria per $\mathrm{ml}$. A total of 324 urine specimens were assayed, with 68 gram-negative urinary tract infections identified as defined by quantitative urine colony counts of $\geq 10^{5}$ bacteria per $\mathrm{ml}$. Of these, 68 and 67 of 68 were detected by the chromogenic Limulus amoebocyte lysate assay at urine dilutions of 1:10 and 1:20, respectively. Nine false-positive chromogenic Limulus amoebocyte lysate assay results were observed at both urine dilutions and in the same specimens. At a urine dilution of 1:10, sensitivity and specificity were 100 and $96.6 \%$, respectively, with predictive values of $100 \%$ for a negative test and $88.3 \%$ for a positive test. At a urine dilution of $1: 20$, sensitivity and specificity were 98.6 and $96.6 \%$, respectively; predictive values were $\mathbf{9 9 . 6 \%}$ for a negative test and $\mathbf{8 8 . 3 \%}$ for a positive test. These data suggest that chromogenic Limulus amoebocyte lysate assay of urine has potential usefulness as a rapid, reliable, and easily performed and interpreted screening test for the diagnosis of clinically significant gram-negative bacteriuria.
\end{abstract}

Aqueous lysates prepared from the circulating cells (amoebocytes) of the horseshoe crab (Limulus polyphemus) gel when exposed to minute amounts of bacterial endotoxin (11). This reaction is the basis of the Limulus amoebocyte lysate (LAL) test, which has been shown to have potential usefulness for rapid diagnosis of gram-negative infections in various body fluids, including cerebrospinal fluid $(8,16)$, urine (17), and urethral and cervical exudates for the presumptive diagnosis of gonorrhea $(15,20,24,25)$.

The biochemical basis of the LAL test is enzymatic (31), with endotoxin, in the presence of calcium, initiating a series of cascading events which result in the activation of a proclotting enzyme present in the lysate (28). The activated clotting enzyme converts soluble proteins (coagulogen) to an insoluble complex (coagulin) $(27,28)$ by cleaving the $L$. polyphemus coagulogen at the Arg-Lys and Arg-Gly linkage $(18,19,28,29)$, resulting in the release of peptide $C$ and formation of the characteristic gel. The proteolytic activity of the activated clotting enzyme has been shown to be active against a number of synthetic chromogenic substrates (7), hydrolyzing the terminal Gly-Arg- $p$-nitroaniline in the following reaction: substrate + enzyme $+\mathrm{H}_{2} \mathrm{O} \rightarrow$ peptide + $p$-nitroaniline. $p$-Nitroaniline is distinctively yellow, and the rate and amount, and thus the color depth, at which it is liberated is a function of the endotoxin concentration in the test sample. Chromogenic substrates have simplified the use of the LAL assay for the detection and quantitation of endotoxin and may further expand the diagnostic usefulness of the assay, having been shown feasible for the detection of gram-negative bacteremia or endotoxemia or both $(5,30)$, meningitis (M. A. Saubolle, T. Barone, A. Blattman, and A. Ramos, Abstr. Annu. Meet. Am. Soc. Microbiol. 1984, C120, p. 256), and gonococcal urethritis in men (21).

Nachum and Shanbrom (17) have described a LAL gelation assay for the detection of gram-negative bacteriuria. The assay is based on the rapid gelation of LAL by the

* Corresponding author. relatively large endotoxin concentrations present in undiluted urine infected with gram-negative bacteria. Gel formation within 10 to $15 \mathrm{~min}$ was shown to be a reliable indicator of $\geq 10^{5}$ gram-negative bacteria per $\mathrm{ml}$ of urine. The rate at which $p$-nitroaniline is released when synthetic substrates are used is directly proportional to the endotoxin concentration (7). Given the potentially large amounts of endotoxin present in the urine of patients with gram-negative urinary tract infections, a study was undertaken to determine whether the chromogenic LAL (CLAL) assay could be used as a visual screening test for the detection of gram-negative bacteriuria. In the present communication, we present data showing that the CLAL urine assay has potential usefulness as a rapid and reliable screening test for clinically significant gram-negative bacteriuria, as defined by the presence of $\geq 10^{5}$ bacteria per $\mathrm{ml}$ of urine (9).

\section{MATERIALS AND METHODS}

Glassware. All glassware used in this study was rendered free of endotoxin by heating in a dry-air oven at $200^{\circ} \mathrm{C}$ for 4 h.

Patient population. Urine specimens were obtained from both inpatients and outpatients complaining of one or more of the following: dysuria, frequency or urgency of urination, and lower abdominal or flank pain. Urine specimens routinely submitted for hospital admission were also included in the study.

Urine collection and culture. Clean-voided urine specimens were collected by patients in sterile midstream collector kits (Concord Laboratories, Keene, N.H.). These kits contained instructions for use and cleansing towelettes impregnated with benzalkonium chloride. Quantitative urine culture was performed with a calibrated $(0.001-\mathrm{ml})$ loop method (1). Urine specimens for culture were inoculated onto one plate each of MacConkey agar and 5\% sheep blood agar (Scott Laboratories, Inc., Carson, Calif.) within 30 min after their receipt in the laboratory. The plates were incubated overnight at $35^{\circ} \mathrm{C}$. If no growth was observed after the initial 
TABLE 1. Results of CLAL assay

\begin{tabular}{lcc}
\hline \multirow{2}{*}{$\begin{array}{c}\text { No. of GNB } \\
(\text { CFU/ml) }\end{array}$} & \multicolumn{2}{c}{$\begin{array}{c}\text { No. of CLAL-positive specimens/total } \\
\text { no. tested at dilution of: }\end{array}$} \\
\cline { 2 - 3 } & $1: 10$ & $1: 20$ \\
\hline$<10^{3}$ & $8 / 221$ & $8 / 221$ \\
$\geq 10^{3}-<10^{4}$ & $0 / 17$ & $0 / 17$ \\
$\geq 10^{4}-<10^{5}$ & $1 / 18$ & $1 / 18$ \\
$\geq 10^{5}$ & $68 / 68$ & $67 / 68$ \\
\hline
\end{tabular}

${ }^{a} \mathrm{GNB}$, Gram-negative bacilli.

incubation period, the plates were reincubated for an additional $24 \mathrm{~h}$. Gram-negative isolates (Enterobacteriaceae) were identified with Micro-ID panels (General Diagnostics, Morris Plains, N.J.), and nonfermenters and gram-positive microorganisms were identified by standard methods (10). Clinically significant bacteriuria was defined by blood agar colony counts of $\geq 10^{5}$ bacteria per $\mathrm{ml}$ of urine (9).

CLAL assay. The CLAL assay system used for this study was obtained from Whittaker M. A. Bioproducts, Walkersville, Md., in kit form (QCL-1000). LAL, chromogenic substrate (S-2423), and reference endotoxin were reconstituted according to the instructions of the manufacturer.

CLAL assay of urine. Upon receipt, 1 to $2 \mathrm{ml}$ of the patient urine specimens was poured into sterile polystyrene capped test tubes ( 12 by $75 \mathrm{~mm}$; Falcon Plastics, Oxnard, Calif.) and held at 4 to $6^{\circ} \mathrm{C}$ until assay ( 2 to $4 \mathrm{~h}$ ). Before assay, urine specimen dilutions of $1: 10$ and 1:20 were prepared in pyrogen-free water (Travenol Laboratories, Inc., Deerfield, Ill.). CLAL assay of the diluted urine was performed as follows: equal volumes $(0.05 \mathrm{ml})$ of the diluted sample and LAL were pipetted into sterile, endotoxin-free disposable borosilicate glass test tubes $(10$ by $75 \mathrm{~mm}$ ) and incubated for $5 \mathrm{~min}$ at $37^{\circ} \mathrm{C}$ in a standing water bath, at which time $0.1 \mathrm{ml}$ of chromogenic substrate, prewarmed to $37^{\circ} \mathrm{C}$, was added to the reaction mixture. The tubes were immediately removed from the water bath, hand-shaken for $5 \mathrm{~s}$, and observed for not more than $30 \mathrm{~s}$ for development of a strong yellow color (positive result). Lack of color development or the formation of a slight yellow tinge was scored as a negative result. Both positive and negative controls were run with each batch of tests, the latter consisting of pyrogen-free water and the former a known culture-positive urine sample.

Endotoxin concentrations in urine were determined by CLAL assay. A standard endotoxin curve (25 to $100 \mathrm{pg} / \mathrm{ml})$ was obtained with Escherichia coli reference endotoxin as supplied in the CLAL kit. Quantitative endotoxin CLAL assay determinations were done by mixing equal quantities $(0.05 \mathrm{ml})$ of the endotoxin reference standards or diluted urine and LAL in endotoxin-free test tubes (10 by $75 \mathrm{~mm}$ ) and incubation for $10 \mathrm{~min}$ at $37^{\circ} \mathrm{C}$, at which time $0.1 \mathrm{ml}$ of chromogenic substrate was added and the tubes were gently shaken and reincubated for an additional $3 \mathrm{~min}$ at $37^{\circ} \mathrm{C}$. The reaction was stopped by the addition of $0.3 \mathrm{ml}$ of a $50 \%$ acetic acid solution, the tubes were vortexed, and absorbance was read at $405 \mathrm{~nm}$ on a Bausch \& Lomb Spectronic 710 spectrophotometer. A negative control consisting of pyrogen-free water was run with each batch of tests, and the optical density of the blank was subtracted from the absorbancies of the test assays. The spectrophotometer was blanked against distilled water.

The minimum concentration of endotoxin per milliliter in culture-positive urine specimens needed to yield a positive CLAL test was determined by twofold dilution in pyrogenfree water, starting at 1:20, until a negative result was achieved. The last dilution to give a positive result was used to calculate the minimum concentration of endotoxin per milliliter of urine needed to yield a positive result within the constraints of the assay, as described above.

Chloroform extraction. CLAL false-positive urine specimens were chloroform extracted (12) by adding $0.25 \mathrm{ml}$ of chloroform to $0.75 \mathrm{ml}$ of undiluted urine and mixing for $3 \mathrm{~h}$ at room temperature, followed by centrifugation at $1,100 \times g$ for $10 \mathrm{~min}$. The middle layer was removed, diluted 1:10 in pyrogen-free water, and tested for endotoxin by CLAL assay.

\section{RESULTS}

Preliminary experiments were performed to determine optimal CLAL assay conditions and the minimum concentration of endotoxin per milliliter of urine needed to yield positive CLAL assays, with five known culture-positive $\left(\geq 10^{5}\right.$ gram-negative $\left.\mathrm{CFU} / \mathrm{ml}\right)$ and two culture-negative $\left(<10^{3} \mathrm{CFU} / \mathrm{ml}\right)$ urine specimens from patients. Data obtained from these experiments established that a 5-min LAL-sample incubation at $37^{\circ} \mathrm{C}$ gave optimal discrimination between culture-positive and culture-negative urine specimens at sample dilutions of $1: 10$ and 1:20. Additionally, at these urine dilutions, the natural color of urine was sufficiently quenched so as not to interfere with the visual reading of the assay. Minimum endotoxin concentrations required for a positive CLAL assay, within the constraints of the assay $\left(5 \mathrm{~min}\right.$ at $37^{\circ} \mathrm{C}$ ), were found to range from 2.0 to $4.1 \mathrm{ng} / \mathrm{ml}$ of urine.

Color development in urine specimens containing $\geq 10^{5}$ gram-negative $\mathrm{CFU} / \mathrm{ml}$ was rapid, with a strong, distinctive yellow color evident within $30 \mathrm{~s}$ after addition of the chromogenic substrate. Lack of color development or the evolution of a slight yellow tinge within $30 \mathrm{~s}$ was scored as a negative result. Increasing the incubation time to $3 \mathrm{~min}$ after the addition of the chromogenic substrate resulted in strong color development in approximately $30 \%$ of patient urine specimens subsequently assayed; however, no correlation with colony counts of $\geq 10^{5}$ gram-negative bacteria per ml of urine was noted. Thus, visual reading of the assay was recorded $30 \mathrm{~s}$ after addition of the chromogenic substrate.

Of the 324 urine specimens cultured and assayed for CLAL activity, 82 were classified as bacteriuric, with 68 $(81.6 \%)$ of gram-negative etiology, including 26 isolations of E. coli, 8 each of Klebsiella pneumoniae and Proteus mirabilis, 2 each of Citrobacter diversus and Pseudomonas aeruginosa, and one each of Morganella morganii, Proteus vulgaris, Hafnia alvei, Enterobacter cloacae, Serratia marcescens, and Acinetobacter anitratus. Polymicrobial gramnegative infections were observed in 16 urine specimens.

Results of CLAL assay of all urine specimens are shown in Table 1. At a urine dilution of $1: 10$, positive CLAL assay results were obtained for all urine specimens containing $>10^{5}$ gram-negative $\mathrm{CFU} / \mathrm{ml}$; however, one false-negative reaction was observed at a urine dilution of 1:20. Nine false-positive reactions were recorded at both dilutions and for the same specimens, with eight of these from urine specimens with quantitative gram-negative colony counts of $<10^{3} / \mathrm{ml}$, and one observed at a count of 12,000 gram-negative CFU/ml. Eight of nine of the CLAL false-positive urine specimens contained gram-positive organisms ranging in counts from $>10^{4}$ to $>10^{5} \mathrm{CFU} / \mathrm{ml}$ (Table 2), with two of these containing probable pathogens, Staphylococcus aureus and group D streptococci (enterococci). The remaining 
six specimens were considered contaminated, with either single or mixed isolations of viridans group streptococci, diphtheroids, or Staphylococcus epidermidis. The one falsepositive CLAL assay result for which no organisms were isolated $\left(<10^{3} \mathrm{CFU} / \mathrm{ml}\right)$ was obtained from a male patient; the other eight were obtained from female patients.

Chloroform extracts were prepared from the nine urine specimens for which false-positive results were obtained. All were successfully retested at a dilution of $1: 10$ by CLAL assay, indicating that the positive CLAL assay specimens were caused by endotoxin present in the urine specimen. To rule out the possibility that endotoxin contamination of the midstream collector jars may have contributed to the endotoxin load of these urine specimens, $20 \mathrm{ml}$ of pyrogen-free water was added to each of five jars and shaken vigorously, and portions were removed and assayed for endotoxin by quantitative CLAL assay. No measurable endotoxin was detected in any of the samples.

Endotoxin concentrations were determined for urine specimens containing $>10^{5}$ gram-negative $\mathrm{CFU} / \mathrm{ml}$ (20 specimens), urine specimens for which false-positive results were obtained (9 specimens), and for urine specimens with $<10^{3}$ gram-negative $\mathrm{CFU} / \mathrm{ml}$ (10 specimens). Urine specimens with $>10^{5}$ gram-negative $\mathrm{CFU} / \mathrm{ml}$ were found to contain high concentrations of endotoxin, ranging from 200 to 2,150 $\mathrm{ng} / \mathrm{ml}$. Endotoxin concentrations in CLAL false-positive urine specimens ranged from 40 to $175 \mathrm{ng} / \mathrm{ml}$. In contrast, true-negative urine specimens $\left(<10^{3} \mathrm{CFU} / \mathrm{ml}\right.$, CLAL negative) contained endotoxin concentrations ranging from a high of 20 to a low of $3.5 \mathrm{ng} / \mathrm{ml}$.

Predictive values (22) for detection of clinically significant gram-negative bacteriuria by CLAL assay are given in Table 3.

\section{DISCUSSION}

The rate of LAL gelation increases with increasing concentrations of endotoxin $(3,11)$. This relationship provided the basis for a previously published study (17) in which rapid LAL gelation (10 to $15 \mathrm{~min}$ ) was used for detection of urine specimens containing $10^{5}$ gram-negative $\mathrm{CFU} / \mathrm{ml}$. In the CLAL test, hydrolysis of the colored complex $p$-nitroaniline from a synthetic substrate is similarily increased by increasing the concentration of endotoxin (7); it was thus postulated that rapid color development might be used as a reliable indicator for screening of urine specimens containing clinically significant numbers of gram-negative bacteria. Prelim-

TABLE 2. Organisms isolated from urine specimens yielding false-positive CLAL assay results

\begin{tabular}{|c|c|c|c|}
\hline $\begin{array}{c}\text { Specimen } \\
\text { no. }\end{array}$ & $\begin{array}{l}\text { Sex of } \\
\text { patient }\end{array}$ & Organism(s) isolated & $\begin{array}{l}\text { No. of } \\
\text { CFU } / \mathrm{ml}\end{array}$ \\
\hline 1 & $\mathbf{F}$ & S. aureus & $>10^{5}$ \\
\hline 2 & $\mathrm{~F}$ & Diphtheroids & $>10^{5}$ \\
\hline 3 & $\mathrm{~F}$ & Enterococci & $>10^{5}$ \\
\hline \multirow[t]{2}{*}{4} & $\mathbf{F}$ & Diphtheroids & $>10^{4}-<10^{5}$ \\
\hline & & Gram-negative bacilli & $1.2 \times 10^{4}$ \\
\hline 5 & $\mathbf{F}$ & Diphtheroids & $>10^{4}-10^{5}$ \\
\hline 6 & $\mathrm{~F}$ & Diphtheroids & $>10^{4}-10^{5}$ \\
\hline 7 & $\mathrm{~F}$ & $\begin{array}{l}\text { Diptheroids, viridans } \\
\text { streptococci, } \\
\text { S. epidermidis }\end{array}$ & $>10^{5}$ \\
\hline 8 & $\mathbf{F}$ & $\begin{array}{l}\text { S. epidermidis } \\
\text { diphtheroids }\end{array}$ & $>10^{5}$ \\
\hline 9 & $\mathbf{M}$ & None & $<10^{3}$ \\
\hline
\end{tabular}

TABLE 3. Predictive values for detection of gram-negative bacteriuria by CLAL assay ${ }^{a}$

\begin{tabular}{ccccc}
\hline \multirow{2}{*}{ Dilution } & \multirow{2}{*}{ \% Sensitivity } & \multirow{2}{*}{ \% Specificity } & \multicolumn{2}{c}{ \% Predictive value } \\
\cline { 4 - 5 } & & & Positive & Negative \\
\hline $1: 10$ & 100 & 96.6 & 88.3 & 100 \\
$1: 20$ & 98.6 & 96.6 & 88.3 & 99.6 \\
\hline
\end{tabular}

${ }^{a}$ Predictive values were calculated as follows: sensitivity, true-positive/ (true-positive + false-negatives) $\times 100$; specificity, true-negative/(true-negative + false-positives) $\times 100$; predictive positive, true-positive/(true-positive + false-positives) $\times 100$; predictive negative, true-negative/(true-negative + false-negatives) $\times 100$.

inary experiments established that $5 \mathrm{~min}$ of incubation of urine-LAL at $37^{\circ} \mathrm{C}$ was sufficient to differentiate urine specimens on the basis of $<10^{5}$ and $>10^{5}$ gram-negative CFU/ml. For assay, urine dilutions of not less than 1:10 were necessary for the following reasons: (i) the natural color of most urine specimens would either mask reading of a positive CLAL assay or, in the absence of bacteriuria, might be interpreted as a positive test; and (ii) low levels of endotoxin shown to be present in urine specimens containing $<10^{3}$ $\mathrm{CFU} / \mathrm{ml}$ might result in false-positive CLAL results. The latter point was confirmed by quantitative data obtained from culture-negative urine specimens, with endotoxin concentrations ranging from 3.5 to $20 \mathrm{ng} / \mathrm{ml}$, amounts shown sufficient to yield positive CLAL assay results in undiluted specimens. Furthermore, endotoxin concentrations of 2.0 to $4.1 \mathrm{ng} / \mathrm{ml}$ in urine were shown to result in positive CLAL assay results within the constraints of the assay procedure, concentrations well within the range shown for nonbacteriuric urines. Thus, dilution of the urine was essential to avoid large numbers of false-positive results.

Nine false-positive CLAL assay results were observed out of a total of 324 urine specimens tested. Chloroform extracts of these specimens were still LAL reactive, indicating that the false-positive CLAL assay results were endotoxin mediated and not the result of nonspecific conversion of the lysate proclotting enzyme to its active form. Of the nine false-positive results recorded, eight were observed for urine specimens obtained from female patients. Two of these specimens contained probable gram-positive pathogens; however, the remaining six were obviously contaminated, as evidenced by the mixed gram-positive flora cultured, indicating improper cleansing before voiding (1). It is possible that the endotoxin detected in these urine specimens was extraneous, i.e., originating from the midstream collector jars, or was the result of in vivo contamination of the specimen. The midstream collector jars were ruled out experimentally as a potential source of endotoxin; thus, it appears that the false-positive results were a result of in vivo contamination of the urine specimen during collection, i.e., either the external (vulva or perineum) or internal (vagina, cervix) genitalia or both. Both sites are known to harbor an indigenous microflora of gram-positive and -negative bacteria $(6,14)$. Additionally, the normal female urethra is frequently colonized by gram-negative organisms (4). These anatomical sites commonly contribute to the bacterial load of urine specimens obtained for culture, especially when adequate cleansing procedures are relaxed (1). Because urine culture was performed at a dilution of 1:1,000 only, gram-negative counts of less than $1,000 / \mathrm{ml}$ could not be ascertained; however, low numbers of gram-negative bacteria or free endotoxin or both might easily have contributed to the endotoxin load (3.5 to $20 \mathrm{ng} / \mathrm{ml})$ shown to be present in 
true-negative urine specimens $\left(<10^{3} \mathrm{CFU} / \mathrm{ml}\right.$, CLAL negative).

The only culture-negative urine specimen $\left(<10^{3} \mathrm{CFU} / \mathrm{ml}\right)$ that yielded a false-positive CLAL assay result was obtained from a male patient. Previously (17), two culture-negative, false-positive LAL urine assay results were described, both for specimens obtained from male patients who had cultureproven gonococcal urethritis. Barring gross contamination of the specimen, it is possible, albeit speculative, that the patient in the present study may have been suffering from either gonococcal or Chlamydia trachomatis urethritis, the latter shown to contain endotoxin and to cause gelation of LAL (13). The large amount of endotoxin (175 $\mathrm{ng} / \mathrm{ml})$ found in this patient's urine, as compared with a mean of $60 \mathrm{ng} / \mathrm{ml}$ \pm 19 present in urine specimens obtained from females and yielding false-positive CLAL assay results, might be viewed as further evidence for urethritis of either gonococcal or chlamydial etiology.

Endotoxin concentrations shown to be present in bacteriuric urine specimens suggest that a considerable percentage of the endotoxin load exists as free endotoxin, i.e., is not cell bound. Endotoxin concentrations per cell of $E$. coli range from $32.5 \mathrm{fg} / \mathrm{ml}$ during the logarithmic phase of growth to a low of $10.0 \mathrm{fg} / \mathrm{ml}$ in the stationary phase (26). It thus appears unlikely that gram-negative urine colony counts of 1 $\times 10^{5}$ to $2 \times 10^{5}$ or greater could account for the endotoxin concentrations reported in urine. These high endotoxin concentrations suggest that dilutions greater than 1:20 would still yield positive assays in bacteriuric urines, thus possibly obviating some of the false-positive CLAL assay results reported in this study.

As presently constituted, CLAL assay of urine has advantages over the use of gel endpoints, providing the user with a more rapid turnaround time, an important aspect for any screening test, and an easily read endpoint. Additionally, problems associated with LAL gel endpoint assays, such as inadvertant dissolution of the gel during either incubation or reading, are obviated by chromogenic assay $(17,23)$.

The results of this investigation have shown that CLAL assay of urine offers a sensitive and reliable screening test for the rapid diagnosis of clinically significant gram-negative bacteriuria for the following reasons: (i) high predictive values are reported for both a positive and a negative assay; (ii) the great majority of bacteriurias are of gram-negative etiology (2); and (iii) the assay is easily performed and interpreted. Thus, CLAL assay could prove useful for routine urine screening in outpatient clinics and physician office practices.

\section{LITERATURE CITED}

1. Barry, A. L., P. B. Smith, and M. Turck. 1975. Cumitech 2 , Laboratory diagnosis of urinary tract infections. Coordinating ed., T. L. Gavin. American Society for Microbiology, Washington, D.C.

2. Blazevic, D. J., J. E. Stemper, and J. M. Matsen. 1972. Organisms encountered in urine cultures over a 10-year period. Appl. Microbiol. 23:421-422.

3. Cooper, J. F., J. Levin, and H. N. Wagner, Jr. 1971. Quantitative comparison of in vitro and in vivo methods for the detection of endotoxin. J. Lab. Clin. Med. 78:138-148.

4. Cox, C. E. 1966. The urethra and its relationship to urinary tract infection: the flora of the normal female urethra. South. Med. J. 59:621-626.

5. Harris, R. I., P. C. W. Stone, and J. Stuart. 1983. An improved chromogenic substrate endotoxin assay for clinical use. J. Clin. Pathol. 36:1145-1149.

6. Hurley, R., V. C. Stanley, B. G. S. Leask, and J. De Louvois.
1974. Microflora of the vagina during pregnancy, p. 155-185. In F. A. Skinner and J. G. Carr (ed.), The normal microbial flora of man. Academic Press, London.

7. Iwanaga, S., T. Morita, T. Harada, S. Nakamura, M. Niwa, K. Takada, T. Kimura, and S. Sakakibara. 1978. Chromogenic substrates for horseshoe crab clotting enzyme. Its application for the assay of bacterial endotoxins. Hemostasis 7:183-188.

8. Jorgensen, J. H., and J. C. Lee. 1978. Rapid diagnosis of gram-negative bacterial meningitis by the Limulus endotoxin assay. J. Clin. Microbiol. 7:12-17.

9. Kass, E. H. 1956. Asymptomatic infections of the urinary tract. Trans. Assoc. Am. Physicians 69:56-64.

10. Lennette, E. H., A. Balows, W. J. Hausler, Jr., and J. P. Truant (ed.). 1980. Manual of clinical microbiology, 3rd ed. American Society for Microbiology, Washington, D.C.

11. Levin, J., and F. B. Bang. 1964. The role of endotoxin in the extracellular coagulation of Limulus blood. Bull. John Hopkins Hosp. 115:265-274.

12. Levin, J., P. A. Tomasulo, and R. S. Oser. 1970. Detection of endotoxin in human blood and demonstration of an inhibitor. J. Lab. Clin. Med. 75:903-911.

13. Lewis, V. J., W. L. Thacker, and S. H. Mitchell. 1979. Demonstration of chlamydial endotoxin-like activity. J. Gen. Microbiol. 114:215-216.

14. Lindner, J. G. E. M., F. H. F. Plantema, and J. A. A. Hoogkamp-Korstanje. 1978. Quantitative studies of the vaginal flora of healthy women and of obstetric and gynaecological patients. J. Med. Microbiol. 11:233-241.

15. Nachum, R., and R. O. Christiansen. 1982. Rapid presumptive diagnosis of gonococcal urethritis in males: evaluation of a prototype Limulus test kit. Med. Lab. Sci. 39:83-85.

16. Nachum, R., A. L. Lipsey, and S. E. Siegel. 1973. Rapid detection of Gram-negative bacterial meningitis by the Limulus lysate test. N. Engl. J. Med. 289:931-934.

17. Nachum, R., and E. Shanbrom. 1981. Rapid detection of gramnegative bacteriuria by Limulus amoebocyte lysate assay. J. Clin. Microbiol. 13:158-162.

18. Nakamura, S., S. Iwanaga, T. Harada, and M. Niwa. 1976. A clottable protein (coagulogen) from amoebocyte lysate of Japanese horseshoe crab (Tachypleus tridentatus). Its isolation and biochemical properties. J. Biochem. 80:1011-1021.

19. Ohki, M., T. Nakamura, T. Morita, and S. Iwanaga. 1980. A new endotoxin sensitive factor associated with hemolymph coagulation system of horseshoe crab (Limulidae). FEBS Lett. 120:217-220.

20. Prior, R. B., and V. A. Spagna. 1982. Rapid evaluation of female patients exposed to gonorrhea by use of the Limulus lysate test J. Clin. Microbiol. 16:487-489.

21. Prior, R. B., and V. A. Spagna. 1983. Rapid evaluation of gonococcal and nongonococcal urethritis in men with Limulus amoebocyte lysate and a chromogenic substrate. J. Clin. Microbiol. 17:485-488.

22. Ransohoff, D. F., and A. R. Feinstein. 1978. Problems of spectrum and bias in evaluating the efficacy of diagnostic tests. N. Engl. J. Med. 299:926-930.

23. Siegel, S. E., and R. Nachum. 1977. Use of the Limulus lysate assay (LAL) for the detection and quantitation of endotoxin, $p$. 61-86. In A. Bernheimer (ed.), Perspectives in toxinology. John Wiley \& Sons, Inc., New York.

24. Spagna, V. A., R. B. Prior, and R. L. Perkins. 1979. Rapid presumptive diagnosis of gonococcal urethritis in men by the Limulus lysate test. Br. J. Vener. Dis. 55:179-182.

25. Spagna, V. A., R. B. Prior, and R. L. Perkins. 1980. Rapid presumptive diagnosis of gonococcal cervicitis by the Limulus lysate assay. Am. J. Obstet. Gynecol. 137:595-599.

26. Sullivan, J. D., Jr., F. W. Valois, and S. W. Watson. 1976. Endotoxin: the limulus amoebocyte lysate system, p. 217-236. In A. Bernheimer (ed.), Mechanisms in bacterial toxinology. John Wiley \& Sons, Inc., New York.

27. Sullivan, J. D., Jr., and S. W. Watson. 1975. Purification and properties of the clotting enzyme from Limulus lysate. Biochem. Biophys. Res. Commun. 66:848-855.

28. Tai, J. Y., and T.-Y. Liu. 1977. Studies on Limulus amoebocyte 
lysate. Isolation of pro-clotting enzyme. J. Biol. Chem. 252: 2178-2181.

29. Tai, J. Y., R. C. Seid, Jr., R. D. Huhn, and T.-Y. Liu. 1977. Studies on Limulus amoebocyte lysate. II. Purification of the coagulogen and the mechanism of clotting. J. Biol. Chem. 252:4773-4776.
30. Webster, C. J. 1980. Principles of a quantitative assay for bacterial endotoxins in blood that uses Limulus lysate and a chromogenic substrate. J. Clin. Microbiol. 12:644-650.

31. Young, N. S., J. Levin, and R. A. Prendergast. 1972. An invertebrate coagulation system activated by endotoxin: evidence for enzymatic mediation. J. Clin. Invest. 51:1790-1797. 